\title{
THE SECURITIES EXCHANGE ACT OF 1934: AN EXPERIMENT IN ADMINISTRATIVE LAW
}

\author{
By ROLAND L. REDMOND †
}

ANY NEW development in the field of government is apt to be controversial. It will have its proponents and its critics. Its possibilities for good will be urged, and its dangers, real or imaginary, will be pointed out with equal vehemence. This is true of administrative law, which has developed rapidly in recent years. ${ }^{1}$ The reasons for this development must be sought in the political and social history of the times. The growing complexity of human society would probably have compelled us to abandon the nineteenth century concept that the function of government should be purely political and that in economic matters the individual and business should be free from governmental control. There is substantial evidence that such a movement was in progress before 1915.2 The exigencies of the World War gave an enormous impetus to this trend. Government was obliged to regulate almost every aspect of civil life in an effort to mobilize national resources for war purposes. Legislative powers were freely granted to the executive or to special agencies organized to regulate civilian activity. ${ }^{3}$ The dangers inherent in such a concentration of power were disregarded in favor of the resulting speed and efficiency of action. Although the powers granted to the executive

TMember of the New York Bar.

1. The use of the term "administrative law" is itself novel, and it has been applied indiscriminately to anything from the inherent power of the sovereign to manage the public domain to the newly developed type of independent commission exercising legiglative, executive, and judicial powers in the regulation of business. See Frankfurter, Foreword to Jennings, Courts and Administrative Law (1936) 49 HARv. L. REv. 426.

2. In the decade preceding 1915 the powers of the Interstate Commerce Commission, for example, had been greatly strengthened. See Sharfman, The Interstate Commerce Commission: An Appraisal (1937) 46 YALE L. J. 915, 933. The Federal Trade Commission Act, and its companion legislation, the Clayton Act, were adopted in 1914. The Federal Reserve Board was established in 1913. It has been pointed out that administrative law may be traced in England at least as far back as the Statute of Sewers [23 HEN. VIII, c. 5 (1531)] and in this country to the Virginia County Courts in Jefferson's time, [See Feller, Prospeclus for the Further Siudy of Federal Administrative Law (1938) 47 YALE L. J. 647], and that the English housing acts had accentuated the movement in that country prior to 1905 . Jennings, op. cil. supra note 1, at 436; Hewart, The New Desporrsa (1929). In the United States the expansion of the administrative process was led by the states. Public Service Commissions were perhaps the most conspicuous examples. Hyneman, Administrative Adjudication: An Analysis (1936) 51 PoL. Scr. Q. 383, 393. Blue Sky legislation, begun in Kansas in 1911, substantially contributed to the tendency. See generally, Freund, Administrative Powers Over Persons and Property (1928).

3. See Fuchs, Concepts and Policies in Administrative Law Theory (1938) 47 YALE L. J. 538. 
and to administrative agencies during the war were only temporary and were revoked as soon as the war emergency had passed, the lesson of how the economic life of the nation might be controlled was not forgotten. In the post war period, the device of creating special executive agencies or of granting unusual powers to some executive department began to be used. ${ }^{4}$ This tendency became overwhelming when new emergencies had to be faced as a result of the depression. In the last five years vast emergency powers have been granted to the executive, and at the same time permanent agencies have been created to regulate a large part of business and industry. ${ }^{\circ}$ This transition has taken place so quickly and in a period of such economic and political confusion that little thought has been given to the ultimate consequences.

I cannot attempt in a brief paper of this kind to analyze the many regulatory acts that have been passed in recent years or to review the results of their operation. Some of the tendencies of administrative law in the United States and some of its practical consequences may, however, be gleaned from an examination of a single statute. With this idea in mind I propose to devote this article to a study of the Securities Exchange Act of 1934, which is of special interest because of the scope of its provisions and the fact that it has been in active operation for nearly three and one-half years, or longer than most of the recently enacted regulatory statutes.

-4. See, e.g., Packers and Stockyards Act, 42 SrAt. 159 (1921), 7 U. S. C. $\S 181$ (1934); Grain Futures Act, 42 Stat. 998 (1922), 7 U. S. C. $\$ 1$ (1934) : Federal Water Power Act, 41 Srat. 1063 (1920), 16 U. S. C. \$792 (1934); Air Commerce Act, 44 Stat. 568 (1926), 49 U. S. C. \$171 (1934); Radio Act of 1927, 44 Sist. 1162, 47 U.S.C. $\$ 81$ (1934); Cotton Standards Act, 42 Srar. 1517 (1923), 7 U.S.C. $\S 51$ (1934); and Sec. 315(a) of Act of Sept. 21, 1922, c. 356, 42 StAт. 941, conferring certain tariff powers upon the President.

5. See, e.g., 48 STAт. 1 (1933), 12 U.S.C. $\$ 95 a$ (1934), authorizing the President to regulate and prohibit foreign exchange transactions and authorizing the Secretary of the Treasury to require surrender of gold; 48 STAT. 52 (1933), 31 U.S.C $\$ 821$ (1934), authorizing the President to direct the issuance of up to $\$ 3,000,000,000$ of United States notes to meet federal obligations; 48 Srar. 52, 342 (1933, 1934) 31 U. S. C. $\$ 821$ (1934), and Act of Jan. 23, 1937, Public No. 1, 75th Cong., 1st Sess., authorizing the President by proclamation to fix the weight of the gold dollar and of the silver dollar within certain limits and to provide for unlimited coinage of silver; 48 STAT. 943 (1934), 19 U.S. C. \$ 1351 (Supp. 1937), conferring flexible tariff powers upon the President in aid of reciprocal trade agreements. See also National Industrial Recovery Act, 48 STAT. 195 (1933), 15 U.S.C. $\$ 701$ (1934); Agricultural Adjustment Act, 48 Stat. 195 (1933), 7 U. S. C. $\$ 601$ (1934); Potato Act of 1935 (repealed) 49 Stat. 782; Tobacco Inspection Act, 49 Stat. 731 (1935), 7 U. S. C. A. $\$ 511$ (Supp. 1937).

6. E.g., Maritime Commission, Securities and Exchange Commission, Commodity Exchange Commission, Federal Power Commission, Federal Bituminous Coal Commission, Federal Alcohol Administration, National Labor Relations Board, National Ifediation Board, and Social Security Bozrd. 
The Securities Exchange Act of 1934 has four main purposes : first, the regulation of securities exchanges $;^{7}$ second, the prevention of the excessive use of credit for speculation $; 8$ third, the prevention of manipulation; $;^{9}$ and fourth, the disclosure of adequate information in regard to securities dealt in on exchanges. ${ }^{10}$ The Act also aims at the prevention

7. Seçurities Exchange Act of 1934, 48 Stat. 881, 15 U.S.C. $\S 78$ a (1934), as amended, 49 Srat. 1375 (1936), 15 U. S. C. A. \$78a (Supp. 1937). Section 5 forbids the use by a broker or dealer of the mails or any instrumentality of interstate commerce for the purpose of using any facility of an exchange to effect or report any transaction in a security unless the exchange has been registered or exempted by the Commission. This, of course, forces exchanges to register. As a condition of registration, an exchange must agree $[\S 6(1)]$ to enforce, so far as is within its powers, compliance by its members with the act and all regulations thereunder and must have in force $[\S 6(4)(b)]$ a rule declaring that the willful violation of the act or any regulation shall be punishable by expulsion, suspension or other discipline. Under $\$ 19(a)(1)$ the Commission - may suspend or withdraw registration if it finds that an exchange has violated the act or any regulation or has failed to enforce compliance by a member or by the issuer of a security registered on the exchange. Under $\$ 19(\mathrm{~b})$ the Commission may request an exchange to alter its rules and, in default of such action, may itself make the alteration. Under $\$ 19$ (a) (3) the Commission may suspend or expel from an exchange any member or officer of an exchange violating the act or any regulation. In addition $\S 32$ provides criminal penalties for willful violations.

8. Section 7 empowers the Federal Reserve Board to fix the amount of credit which members of exchanges and other brokers or dealers doing business through members may extend or maintain on registered non-exempt securities, and generally forbids the extension of credit for the purpose of purchasing or carrying securities on other collateral or without collateral. Section $7(d)$ empowers the Federal Reserve Board to regulate, with certain exceptions, the extension of credit for purchasing or carrying registered securities by any other person. Section $8(a)$ requires members of exchanges, and brokers or dealers doing business through them, to borrow in the ordinary course of business only from banks which are members of the Federal Rescrve System, or which have agreed to comply with the federal laws and regulations governing the use of credit in security transactions, or from other members, brokers, or dealers under rules laid down by the Federal Reserve Board. Violation of any of these provisions is made unlawful.

9. Section 9 defines certain- types of unlawful manipulative practices, and authorizes the Commission to make regulations with respect to other types of transactions which might be used for manipulative purposes, such as transactions in options. Section 9(e) implements the criminal penalties of the act by making a person guilty of a prohibited manipulative practice civilly liable to anyone injured thereby. Section 10 gives the Commission a general power to make regulations with respect to other manipulative or deceptive practices and with respect to short sales and stop-loss orders. Section 15(c) gives the Commission power to define what devices or contrivances employed in the over-the-counter markets are manipulative, deceptive, or otherwise fratudulent. A violation of such regulations is made unlawful.

10. Section 12(a) makes it unlawful for any member, broker, or dealer to effect any transaction on an exchange in any security (other than an exempted security) unless a registration is in effect as to such security. To secure registration a detailed registration statement must be filed, and an exchange must certify its approval of the security for listing. Under $\S 13$, every issuer of a registered security must file periodical 
of unfair methods in the solicitation of proxies in regard to such securities $^{11}$ or the use, for personal profit, of confidential information by the directors, officers or principal stockholders of the issuers of such securities. ${ }^{12}$

Control of securities exchanges is accomplished by making their registration a condition precedent to the lawful transaction of business. ${ }^{13}$ The Commission may deny, suspend, or revoke any registration, and it likewise has power to compel registered exchanges to make such changes in their rules and practices as the Commission may deem necessary to insure fair dealing on such exchanges. ${ }^{14}$ The registration of brokers and dealers engaged in business in the over-the-counter markets is likewise required..$^{15}$ The Commission, through its power to suspend or expel from membership any member or officer of an exchange and its right to revoke any registration, has a direct and effective power over exchanges, members of exchanges, and over-the-counter brokers and dealers. ${ }^{16}$ The disciplinary power of exchanges is made an additional means of enforcement by requiring each registered exchange to incorporate in its rules the provisions of the Act and of the rules and regulations adopted thereunder. Each exchange must also agree to comply with "and to enforce so far as is within its power compliance by its members" with the Act and any rule and regulation made thereunder. ${ }^{17}$ The Federal Reserve Board is given broad power to adopt rules and regulations with regard to the use of credit and the Commission is given equivalent power in regard to many other matters. ${ }^{18}$ The Act and many of the rules and

reports in the form and containing the information prescribed by the Commission. Section $12(f)$ allows trading in unregistered securities under certain conditions but only when approved by the Commission.

11. Section 14 authorizes the Commission to make rules with respect to the solicitation of proxies on registered securities and with respect to the giving of proxies by members, brokers, or dealers on securities carried by them for customers.

12. Section $16(a)$ requires periodical reports from officers, directors, and principal stockholders of companies having equity securities registered on an exchange, which reports are designed to afford a public record of all transactions by such reporting persons in the equity securities of their companies. Section 16(b) makies any such reporting person liable to account to his company for any profit made by him from the purchase and sale within six months of any such equity security, the accountability being enforceable either by the company or by any owner of any security so bought and sold. Section 16(c) prohibits such reporting persons from selling "clart" equity securities of their companies.

13. Section 5 .

14. Sections 19 (a) (1), 19 (b).

15. Section $15(\mathrm{a})$.

16. Section 19(a)(3), Sec 15(b), Sec 19(a)(1).

17. Sections $6(\mathrm{a})(1), 6(\mathrm{~b})$.

18. General power to make rules and regulations was given both to the Reserve Board and the Commission by $\$ 23(\mathrm{a})$. For specific powers of Federal Reserve Board, see $\S \S 7$ and 8 . For specific powers of Commission see $\S \S 6,8$ to 17 inclusive, 19 , and 30 . 
regulations so adopted are made effective by criminal penalties. ${ }^{10}$ As an additional sanction, the Commission may invoke the aid of the courts to enforce its orders by injunction or mandamus. In order to give force to these sanctions, the Commission has been given broad powers of investigation. It may also make public its findings $;^{20}$ the possibility that publicity may be an effective means of regulation has been recognized by a former chairman of the Securities and Exchange Commission. ${ }^{21}$

The Act also contains a number of civil penalties intended to implement its provisions. The obligation of directors, officers and principal stockholders to account for profits realized on purchases and sales made within a six months' period can be enforced by the issuer or any owner of the securities concerned. ${ }^{22}$ Any person who purchases or sells a security at a price which was affected by a violation of the anti-manipulative provisions of the Act may recover damages from any person who wilfully participated in the forbidden act. ${ }^{23}$ Any one who purchases or sells a security at a price which was affected by a false or misleading statement in any document filed pursuant to the Act, or any rule or regulation thereunder, may recover damages from whoever made the false statement or caused it to be made. ${ }^{24}$ Every contract made in violation of any provision of the Act or of any rule or regulation thereunder, or the performance of which involves such a violation, is declared void and may be set aside at the instance of any person who did not have knowledge of its illegality at the inception of the contract. ${ }^{25}$

The members of the Securities and Exchange Commission were appointed in July, 1934. The first few months were devoted to securing an adequate staff and to preparing for the registration of exchanges and the temporary registration of listed securities, which under the Act had to be effected by October 1,1934 . If we disregard this initial stage, the Commission has been in active operation for practically three

Rules and regulations may be promulgated without notice and without a hearing. See $\S 23(\mathrm{a})$.

19. Section 32. For an excellent discussion, see Herlands, Criminal Law Aspects of the Securities Exchange Act of 1934 (1934) 21 VA. L. REv. 139. Making the violation of such rules or regulations a crime is completely novel, having never been done in foreign countries where securities exchanges have been regulated for many years. See Nussbaum, American and Foreign Stock Exchange Legislation (1935) 21 VA. L. REv. 839, 850.

20. Sections $21(\mathrm{e}), 21(\mathrm{f})$, and $23(\mathrm{a})$.

21. Landis, Significance of Administrative Commissions, (1937) 12 IND. L. J. 471, 478: "A notable device, full of potential danger and yet possessing enormous force, is that simply of publicity."

22. Section 16(b).

23. Section 9(a).

24. Section 18(a).

25. Section 29 (b). 
years. During this period much has been accomplished. All the major exchanges of the country have been registered, and, with few exceptions, all securities listed on exchanges have been permanently registered. The Federal Reserve Board has adopted regulations governing extensions of credit by members of national securities exchanges, brokers, and dealers, ${ }^{, 0}$ and in regard to loans by banks for the purpose of purchasing or carrying stocks registered on a national securities exchange. ${ }^{27}$ More than 6500 brokers and dealers engaged in business in the over-the-counter markets have been registered. The Commission has investigated a large number of suspected cases of manipulative practices, and has made several formal investigations of important topics which have been the subject of lengthy reports to Congress. A great amount of statistical and other data has been assembled. A number of proceedings looking towards the suspension or expulsion of members of exchanges have been initiated. ${ }^{28}$ The activity of the Commission has been little short of amazing, particularly when consideration is given to the fact that it is also charged with the administration of the Securities Act of 1933 and the Public Utility Act of 1935.

Some idea of the volume of the Commission's work may be gathered from the fact that prior to January 1, 1938, the Commission issued more than 1500 releases relating solely to the Securities Exchange Act of 1934. While merely in the form of announcements to the press, these releases constitute the only complete current source of official information as to the work of the Commission. They contain copies of the rules and regulations prescribed by the Commission, copies of its orders and of its opinions, statistical data in regard to the registration of securities, the forms which the Commission has adopted for the registration of securities and of dealers and brokers, and tabulations showing the extent and nature of transactions on national securities exchanges. Important opinions of General Counsel to the Commission are also frequently published in this manner. It is difficult to grasp the extent of the work of the Commission without actually examining these releases. Their number alone is impressive, but a better idea of them may be secured from the fact that in one of the commercially published services the forms adopted by the Commission, together with their accompanying instruction books, occupy more than 675 printed pages. ${ }^{20}$ In another service the rules and regulations of the Commission currently in force occupy more than 80 printed pages. ${ }^{30}$ The mere mass of this material presents

26. See Regulation T, Prentice-Hall Securities Reg. Serv. [I] 10,784-10,946. For revision effective January 1,1938 , see $\{14,023$ et seq.

27. Id., at III 10,951-10,982.

28. Securities and Exchange Commission, Tamn Amrual Refort (1937) at 71.

29. Prentice-Hall Securities Reg. Serv. II 12,021 et seq.

30. New York Stock Exchange Directory and Guide, at H41 ef scq. 
a serious problem to the persons subject to regulation and to lawyers who are called upon to advise them. Another equally serious problem is the rapidly changing nature of the rules and regulation: promulgated under the Act. Many rules have been amended, and many forms of registration have been changed. As an instance of this I might cite the fact that Regulation $T$, originally adopted by the Federal Reserve Board in September 1934 in the form of a printed pamphlet of sixteen pages in length, has been amended eleven times and has been the subject of fortyeight interpretative rulings adopted by the Board itself. ${ }^{31}$ A general revision, which changed the regulation in many important particulars, became effective on January $1,1938 .^{32}$ As a consequence, acts legal one day became criminal the next. In the face of such rapid change, the average layman feèls entirely incapable of determining whether a contemplated transaction is lawful or unlawful. It is, of course, too soon to conclude that constantly changing regulations, forms, and requirements are a necessary consequence of this type of administrative law, but the tendency in this direction must be noted with concern. ${ }^{33}$

31. See note 26 , supra.

32. See Regulation $T$ as revised by circular of the Board of Governors of the Federal Reserve, effective January 1, 1938; see supra note 26.

33. Although it has been stated that the main purpose of the margin provisions was "to give a Government credit agency an effective method of reducing the aggregate amount of the nation's credit resources which can be directed by speculation into the stock market and out of other more desirable uses of commerce and industry . . ." [73rd Cong,, $2 d$ Sess., H. R. No. 1383, 8], the Act seems to go further than is necessary in that it regulates not only the source of credit but also the specific use of credit by members of an exchange and brokers or dealers transacting business through such members. Section 8 controls the source of credit by providing that except in certain special cases members of exchanges and brokers or dealers transacting business through them may borrow on registered securities only from a member bank of the Federal Reserve System or from a bank which has agreed to comply with the Securities Exchange Act, the Federal Reserve Act and the Banking Act of 1933 [Act of June 16,1933 , c. $89, \S 7,48$ STAT. 162]. The borrowings of other persons from such a bank for the purchase or carrying of a registered security are likewise subject to regulation, if a registered stock is collateral for the loan. See $\S 7(d)$ and Regulation U of Federal Reserve Board promulgated thereunder. These provisions, taken in connection with the power given the Federal Reserve Board by the Banking Act of 1933 to fix the percentage of their funds which member banks may lend upon stock or bond collateral [48 STAT. 167; 12 U.S. C. A. $\$ 248(\mathrm{~m})$ (1934)], would seem to be adequate to permit the Federal Reserve Board to regulate the aggregate amount of credit available for speculation. The complexity of the regulations and their frequent change has been due largely to the fact that the Act, in addition to controlling the aggregate amount of credit, attempts to regulate in detail the use of such credit by members of exchanges and dealers or brokers transacting business through such members. See $\S 7$ (a), (b) and (c). The burden imposed by this type of regulation is of course increased by the fact that a willful violation is made a criminal offense and that a violation, even if not willful, renders an exchange member subject to proceedings by the Commission for suspension or expulsion. If, in addition to controlling credit at its source, it is 
The registration of substantially all the securities listed on national securities exchanges is one of the most important achievements of the Commission during the first three years of its administration. Under the Act temporary registration could be granted until July 1, 1935, on such terms and conditions as the Commission saw fit to impose. The Commission wisely determined to facilitate this type of registration. Only a statement of the name of the security to be registered and the amount outstanding or available for registration was required. ${ }^{34} \mathrm{~A}$ vast majority of the securities listed on exchanges were temporarily registered before October 1, 1934. The Commission granted exemptions for certain types of securities, notably foreign government obligations, so that the requirement of temporary registration did not result in the removal of any large volume of securities from the exchanges. ${ }^{35}$ The forms adopted for the permanent registration of securities were of a very different character. ${ }^{86}$ They called for a large amount of statistical and historical information. As the Act imposes a civil penalty on any false or misleading statement made in connection with a registration, those applying for registration have tended to quote original documents instead of employing brief and enlightening summaries. This has resulted in unduly voluminous registration statements which are of little practical value except to the expert analyst. The Commission has recognized the difficulty created by verbose statements and has endeavored in the adminis-

thought desirable to protect the individual customer from his own excessive speculation, this might be accomplished by requiring exchanges to adopt margin rules approved by the Commission.

34. Rules JE1 and JE2, promulgated Aug. 13, 1934, repealed by Release No. 990, Dec. 21, 1936. See forms 2 and 3, Prentice-Hall Securities Reg. Serv. III 12,022 and 12,032; cf. Rule JB2, promulgated Sept. 29, 1934, as amended by Releases Nos. 93, Feb. 14, 1935 and 990, Dec. 21, 1936, and form 7, Prentice-Hạll Securities Reg. Serv. I1 12,070, providing for provisional registration of securities in cases where no applicable forms have been promulgated, pursuant to Rule JB1 as amended by Release No. 858, Sept. 28, 1936.

35. Approximately 50 issues out of the 2,768 issues listed upon the New Yorl: Stock Exchange were removed because of failure of the issuers to file statements for temporary registration in cases where form 2 [see supra, note 34] was applicable. Circulars of Committee on Stock List of New York Stock Exchange, C-5602, July 10, 1935; C-5604, July 13, 1935; C-5667, Oct. 25, 1935.

36. Rule JB1 prescribes the appropriate forms for various classes of isevers, including unincorporated issuers, certain issuers subject to the jurisdiction of the Interstate Commerce Commission, insurance companies, committees issuing certificates of deposit, voting trustees, foreign governments, foreign private issuers, issuess in insolvency proceedings, successor issuers, bank holding companies, and others. The basic form is form 10 for corporations, promulgated Dec. 21, 1934, Release No. 66. To appreciate the detailed information which must be given, the instruction bools provided for this form [Prentice-Hall Securities Reg. Serv. [1 12,123] should be consulted. The information is to be kept current pursuant to $\$ 13$ of the Securities Exchange Act by annual reports filed on form 10-K, adopted by rule KA1, Release No. 445, Dec. 20, 1935. 
tration of the Securities Exchange Act of 1934, as well as in the administration of the Securities Act of 1933, to persuade applicants for registration to summarize their replies and to use non-technical forms. ${ }^{37}$ Little progress, however, has been made in this direction.

In certain particulars the work of the Commission in the field of the registration of securities has had important and beneficial results. The insistence of the Commission upon financial statements audited by independent accountants has given a new impetus to the movement initiated a number of years ago by the principal stock exchanges. ${ }^{38}$ The Commission has also urged the standardization of accounting practices and has given to auditors and accountants a new importance which will undoubtedly lead to the adoption of sounder accounting methods. The requirements of the Act have forced the disclosure of the remuneration of officers, directors, and all others receiving $\$ 20,000$ or more per annum. The commission has insisted upon the disclosure in the income account of "sales" and "cost of goods sold." 39 Whether such information should be published in all cases is a debatable question, and a number of proceedings are now pending in the courts to test the legality of the Com-

37. The Commission has made extensive efforts to encourage brevity and simplicity in prospectuses under the Securities Act of 1933. S. E. C. Gen. Rules and Regulations 821-838; Securities Act Releases Nos. 874, July 2, 1936, and 1503, July 12, 1937. But so long as the issuer remains a guarantor of the truth of a registration statement [Securities Act, §11] there is little basis for believing that this aim can be achieved. See Dean, The Lawyer's Problems in the Registration of Securities (1937) 4 LAW \& Contem. ProB. 154, 157-161. Similar efforts have been made by the Commission under the Securities Exchange Act of 1934. E.g., Release No. 66, Dec. 21, 1934; Rule JB4, Release No. 98, Feb. 14, 1935; and General Rule 6 in the instruction book to Form 10, Prentice-Hall Securities Reg. Serv. IT 12,123.2 and 12,123.31. However, good faith is a defense in a civil action under $\S 18$ of the Securities Exchange Act of 1934, although the defendant has the burden of proof, and this fact may ultimately lead to simpler registration statements under the latter Act.

38. The Act leaves it to the discretion of the Commission whether financial statements shall be so certified in registration statements. $\$ 12(\mathrm{~b}) 1(\mathrm{I})$ and $(\mathrm{J})$, and in annual reports, $\S 13(\mathrm{a})(2)$. Stich certification is required by the Commission in the instruction books to Form 10, Prentice-Hall Securities Reg. Serv. $\llbracket 12,123.46$, p. 12,101 and Form 10K, Prentice-Hall Securities Reg. Serv. $\pi 12,133.19$, p. 12,126. See however, Rule KA5, Release No. 527, March 14, 1936, waiving certification of interim * reports where the period to be covered is less than six months. Compare S.E.C. General Rules and Regulations, setting forth the qualifications required of accountants and the Commission's definition of "independent." As to the progress which had been made by the exchanges in obtaining independent audits of financial statements, see announcement of president of New York Stock Exchange, January 6, 1933, and address by J. M. B. Hoxsey, Executive Assistant of the Committee on Stock List of the New York Stock Exchange, "Accounting for Investors," September 30, 1930.

39. See instruction books to forms 10 and $10 \mathrm{~K}$ as to requirements for profit and loss statements with respect to cost of goods, sold, Prentice-Hall Securities Reg. Serv.

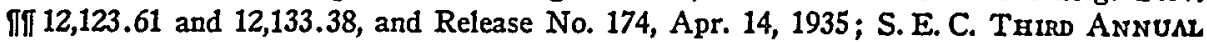
REPORT (1937) 178. 
mission's conclusion that publication should be made even when the responsible officers of the registrant believe that publicity will adversely affect the interests of their company. ${ }^{40}$

The problem of the amount of information to be required as a condition of registration presents one of the most difficult questions which the Commission must solve. Under the Act an applicant for registration must furnish, with respect to many matters, information in such detail "as the Commission may by rules and regulations require, as necessary or appropriate in the public interest or for the protection of investors." "11 This standard itself presents difficulties. In many instances a publication justifiable "in the public interest" would undoubtedly be harmful to the persons who had invested in the enterprise. A nice question therefore exists as to which part of the standard should control. The problem is not a new one. It has been faced for many years by the listing committees of exchanges. In general, these private bodies have not insisted upon the publication of data which responsible officials of the company have, for apparently valid reasons, urged should be treated as confidential. It is at least open to question whether this policy is not preferable to one which would invariably require full and complete disclosure. There are many trade secrets and a variety of other facts in the possession of management which could not be published without serious detriment to the business. The Act recognizes this fact and expressly provides that nothing in it "shall be construed to require, or to authorize the Commission to require, the revealing of trade secrets or processes." 42 Whether this exception should be enlarged in scope, or whether the Commission in administering the law should interpret liberally its power to grant confidential treatment to data filed with it, is still to be determined.

Another important part of the work of the Commission has consisted in carrying out the directions of Congress to make certain formal investigations. The Act directed the Commission to study and report on "the feasibility and advisability of the complete segregation of the functions of dealer and broker" 43 and on "the rules of national securities

40. See S.E.C. Third Annuat Report, (1937) 179, Table $X$. It was held that the Commission's determination under $\$ 24(b)$ to make public information for which confidential treatment had been requested was reviewable under $\$ 25$ (a) in American Sumatra Tobacco Corporation v. Securities and Exchange Commission and related cases. United States Court of Appeals for the District of Columbia, Sspt. 30, 1937. Prentice-Hall Securities, Reg. Serv. $\llbracket 14,017$.

41. Section $12(\mathrm{~b})(1)$.

42. Section $24(a)$. Under $\$ 24(b)$ objection may be made to the public disclosure of information contained in any report or document filed with the Commission, and in such case the Commission may make public disclosure thereof only when in its judgmenit it is in the public interest to do so. However, the number of such objections which are sustained by the Commission is small. See S.E. C. Trmo Arsiurr Refora (1937) 178.

43. Section $11(\mathrm{e})$. 
exchanges with respect to the classification of members, the method of the election of officers and committees to insure a fair representation of the membership and the suspension, expulsion and disciplining of members of such exchanges." 44 An admittedly preliminary report on the first of these subjects was transmitted to Congress on June 20, 1936. It analyzed current methods of trading and dealt particularly with the combination of dealer-broker functions on exchanges and in the overthe-counter markets. A large section was devoted to the economic implications of segregation. While the method of compilation and the significance of the statistical data on which the Commission based some of its findings have been questioned, and its general conclusions as to the need for an active liquid market and the effect of combining the functions of broker and dealer seem difficult to justify, the report is important because of the information it contains in regard to stock exchange practices. ${ }^{45}$ A report on the second subject was submitted to Congress on January 25, 1935. It contains a factual study of the organization of the various exchanges of the country and certain recommendations in regard to the desirability of greater representation of firms engaged in the commission brokerage business and of a more liberal method of selecting candidates for exchange offices. ${ }^{46}$

The Commission was also directed to make a study and investigation of "the work, activities, personnel and functions of protective and reorganization committees in connection with the reorganization, readjustment, rehabilitation, liquidation or consolidation of persons and properties." Pursuant to this mandate the Commission submitted to Congress a report in six parts. ${ }^{47}$

These reports represent the result of lengthy investigations carried out by the Commission during the course of which, both by questionnaire and direct testimony, a large amount of evidence and statistical data was collected. They are particularly significant because of the recommendations contained in them for further legislation looking towards a great increase in the administrative duties of the Commission. They led directly to the introduction of the Barkley and Lea Bills. ${ }^{48}$ The former

44. Section $19(c)$.

45. S.E. C. REPort of the FeasibILIty and Advisability of the Complett Segregation of the Functions of Dealer and Broker, June 20, 1936.

46. Securities Exchange Act of 1934, Title II, §211.

47. Part I, Strategy and Techniques of Protective and Reorganization Consmittees, May 10, 1937; Part II, Commitrees and Conflicts of Interest; Part III, Committees for the Holders of Real Estate Bonds; Part IV, Committees for tue Holders of Municipal and Quast-Municipal Obligations; Part V, Protective Committees and Agenctes for Holders of Defaulted Foreign Governadental Bonds; Patt VI, TRUSTEEs UNDER INDENTURES.

48. Barkley Bill: S.2344, 75th Cong., 1st Sess. (1937); Lea Bill: H. R. 6968, 75th Cong., 1st Sess. (1937). 
bill would give the Commission broad powers to approve or disapprove the provisions of corporate trust indentures and would also impose upon trustees more active duties and a greater measure of liability. The second would require every person soliciting a proxy in regard to any reorganization, recapitalization, or other corporate change to file a registration statement analogous in many respects to the registration statements required under the Securities Act of 1933. These reports also had a direct effect upon the Chandler Bill, ${ }^{49}$ which would amend the Bankruptcy Act and in the case of $77 \mathrm{~B}$ reorganizations would give the Commission the right to intervene in the proceedings and would require it to consider and report on any plan of major corporate reorganization.

These reports are worthy of careful study because they disclose the tendency of an administrative commission to expand constantly the scope of its activities. In one respect, at least, they run counter to the principle embodied in both the Securities Act of 1933 and the Securities Exchange Act of 1934 that the Commission should not exercise its discretion or judgment as to the value or soundness of a security but should confine its activities to obtaining an amount of information sufficient to allow the persons buying or selling the security to determine or appraise its value. $^{50}$ This limitation is emphasized by the provisions contained in both acts making it a criminal offense to represent that any action, or failure to act, of the Commission means that it has passed upon the merits or approved any security. ${ }^{\text {b1 }}$ Even the right to refuse or revole a registration is limited. In the case of the Securities Act of 1933, such an order can be entered only if the Commission finds that the registration statement is deficient or contains untrue or misleading statements. ${ }^{52}$ Under the Securities Exchange Act of 1934, registration.may be denied, suspended, or revoked only when the Commission has determined that the issuer has failed to comply with the Act or the rules and regulations thereunder. ${ }^{53}$ Unless one of these findings can be made, the Commission is without power to refuse or revoke a registration even if it is convinced that the sale of the security, or its listing on an exchange, would be undesirable in the public interest. The powers which the Barkley Bill and the Chandler Bill propose to vest in the Commission are of a quite different character and would require the Commission to exercise its discretion as to the fairness of corporate trust indentures and plans of reorganizations.

49. H. R. 8046, 75th Cong., 1st Sess. (1937).

50. See $\$ \S 6$ and 7, Securities Act of 1933, 48 Sт八т. 74, 15 U.S.C. $\$ 77 a$ (1934); Securities Exchange Act $\$ 12$.

51. Securities Act of 1933, §23; Securities Exchange Act, $\$ 25$. See also S.E. C. General Rules and Regulations, Rule 825.

52. Securities Act of 1933, $\S \S 8(b)$, (d).

53. Securities Exchange Act of 1934, $\$ 19$ (a) (2). 
Another instance of the tendency of the Commission to enlarge the scope of its powers should be noted. The Act authorized any national securities exchange to continue until June 1, 1936 unlisted trading privileges in respect of any security which had been admitted to dealing on such exchange prior to March 1, 1934, and directed the Commission to study and report on the trading in unlisted securities upon exchanges. Such a report was duly filed with Congress and recommended important amendments to the Act. ${ }^{54}$ Not only was the continuance of unlisted trading made subject to the approval of the Commission, but it was extended to securities registered on other national securities exchanges and to any security as regards which there was available from a registration statement, or other data filed with the Commission under the Securities Act of 1933 or the Securities Exchange Act of 1934, information substantially equivalent to that available as regards a security duly listed and registered on a national securities exchange. ${ }^{.5}$ At the same time, and as part of the same amendments, the power of the Commission to regulate over-the-counter markets was greatly increased. The registration of brokers and dealers engaged in business in such markets was made mandatory, and the Commission was given certain powers to deny or revoke any such registration. ${ }^{58}$ In addition, each registration statement thereafter filed pursuant to the Securities Act of 1933 was required to contain, in the case of any major issue, an undertaking by the issuer to file with the Commission, in accordance with such rules and regulations as the Commission might prescribe, supplemental and periodic information and reports equivalent to those required in respect of a security listed and registered on a national securities exchange. ${ }^{57}$ The purpose of these amendments was to increase the number of securities available for trading on national securities exchanges and at the same time to regulate and control more effectively the over-the-counter markets. The significant change made by these amendments was the substitution of the discretion of the Commission for that of exchanges in determining what securities should be available for exchange markets.

The question of conferring increased power upon an administrative agency is a substantive one to be settled by the legislature. Once the decision to increase the scope of regulation has been made, the problem resolves itself into a determination of whether an existing agency or a new one created for that purpose is best suited to carry out the legislative intent. A variety of considerations may influence this decision ${ }^{68}$

54. Securities and Exchange Commission, Report on Trading in Unisted Securities upon Exchanges (1936).

55. See Securities Exchange Act of 1934, $\S 12(\mathrm{f})$, as amended.

56. Securities Exchange Act of $1934, \$ 15$, as amended.

57. Securities Exchange Act of 1934, $\$ 15$ (d).

58. See Feller, op. cit. supra note 2, at $652 \mathrm{ff}$. 
and among the most potent will be the recommendations of an existing administrative agency already charged with regulating a similar field of activity. It is in this connection that the tendency of administrative commissions to perpetuate and to increase their administrative powers becomes important. As might be expected, the recommendations of an administrative agency will always be towards the augmentation of its power. Even though its functions may have become unnecessary, it is hardly likely that such an agency will recommend to Congress that its activities be curtailed or discontinued. This tendency should be the subject of critical scrutiny, and such requests for enlarged powers should be granted only when the legislature has become convinced that they are essential for the accomplishment of some necessary economic or political purpose.

The Commission has made many informal as well as formal investigations. Under the Act the Commission may "in its discretion make such investigations as it deems necessary to determine whether any person has violated or is about to violate any provision" of the Act or of any rule or regulation thereunder." It is also authorized "to investigate any facts, conditions, practices, or matters which it may deem necessary or proper to aid in the enforcement of the provisions of this title, in the prescribing of rules and regulations thereunder, or in securing information to serve as a basis for recommending further legislation concerning the matters to which this title relates." cs Pursuant to these powers the- Commission has under regular observation approximately 3000 issues dealt in on national securities exchanges or over-the-counter markets. $^{61}$ During the fiscal year ended June 30,1937, it investigated many hundreds of instances of suspected manipulation which were the subject of reports in 420 cases and of preliminary investigations in 72 cases. $^{\text {c2 }}$

The Act gives the Commission power to suspend for a period not exceeding twelve months or to expel from a national securities exchange any member or officer thereof whom the Commission finds has violated any provision of the Act or of the rules and regulations thereunder. ${ }^{63}$ Pursuant to this provision, the Commission has instituted eight proceedings. $^{64}$ In one case the proceedings were terminated by the entry of an order of expulsion with the consent of the respondent ; $^{65}$ in another,

59. Securities Exchange Act of 1934, $\$ 21(\mathrm{a})$.

60. Ibid.

61. S.E.C. Third Annual Report (1937) 69.

62. Id., at 70.

63. Securities Exchange Act of 1934, $\$ 19$ (a)(3).

64. For details of the first seven proceedings, see S.E.C. Trind Asisual Reront (1937) 71. The eighth, instituted against certain partners of E. F. Hutton \& Co., and others, was commenced by telegraphic notice served on December 31, 1937.

65. In the Mfatter of Thomas F. Gagan, et al., October 6, 1937. Ibid. 
because of the expulsion of the respondent from membership by a national securities exchange $;^{66}$ in a third, because of the respondent's resignation from membership in a national securities exchange. ${ }^{67}$ Of the remaining five cases, only one has been concluded by the entry of an order expelling the respondent from membership on national securities exchanges ${ }^{68}$ two are under consideration by the Commission; one is pending before a trial examiner; and the last, which was initiated on December 31, 1937, has been referred to a trial examiner for hearing. ${ }^{60}$

In many respects these proceedings are of the greatest significance. They represent the use of a novel and unusual sanction for the enforcement of a federal statute. ${ }^{70}$ They are in the nature of criminal proceedings, as the penalty of expulsion or suspension may have far greater consequences than any fine which might be imposed under the Act. Expulsion from national securities exchanges.and the refusal of registration as a broker or dealer in the over-the-counter markets, which would necessarily follow a violation of the Act, would effectively bar the respondent from the right to engage in the securities business. The very means of livelihood may therefore be taken away from the person subject to this form of penalty. Unlike the criminal provisions of the Act, any vioiation of the Act or a rule or regulation thereunder may be a ground for suspension or expulsion even if it is not wilful. Taken in connection with the provision that in any subsequent court review the findings of the Commission as to the facts shall be conclusive if supported by substantial evidence, the power of the Commission in this type of proceeding must be considered with a grave concern. ${ }^{71}$ To persons trained in the tradition of Anglo-American law there is something abhorrent in the idea that any single group may make laws, may act as

66. In the matter of Harry A. Dart, et al., May 13, 1937. Ibid.

67. In the matter of Abbott, Proctor \& Paine, et al., June 17, 1937. Ibid.

68. See In the matter of M. J. Meehan, Securities and Exchange Commission, Release No. 1358.

69. In the matter of Charles C. Wright, et al., and In the matter of Harold $T$. White, et al., are pending before the Commission; In the matter of W. E. Hutton, et al., is before a trial examiner for a report on findings. Ibid. As noted, supra note 64, proceedings against certain partners of E. F. Hutton \& Co., et al., have just been instituted.

70. Landis, op. cit. supra note 21 , at 475 . "Further characteristic of these agencies is the new and novel sanctions given to them to carry out their policies. Those possessed by courts have been limited to relatively few in character. But the very creation of an administrative agency implies a consideration of new sanctions in aid of enforcement. For example, the Securities and Exchange Commission is armed with sanctions never possessed by courts, but commonly vested in the governing boards of stock exchanges, such for instance, as suspending and expelling members from exchanges or suspending securities from being traded in on exchanges."

71. Securities Exchange Act of 1934, §25(a). 
a public prosecutor in enforcing those laws, and may then determine the guilt or innocence of the person it has accused. ${ }^{72}$

From the four proceedings of this nature which have been the subject of hearings, certain conclusions may be drawn in regard to the Commission's procedure. In all these cases a violation of the anti-manipulative section of the Act was charged. The orders to show cause why the respondents should not be suspended or expelled from national securities exchanges set forth the alleged violations in the language of the statute. ${ }^{\text {T3 }}$ The only particulars disclosed in the notice to the respondents or in the order to show cause, which was subsequently served upon them, were the name of the security alleged to have been manipulated and the approximate period within which manipulation was alleged to have taken place. ${ }^{74}$ Further particulars were denied in some cases and furnished in others in incomplete form or subject to restrictive conditions. ${ }^{75}$ The Commission has justified its refusal to give a comprehensive bill of particulars on the ground that the notice specified by the statute does not require that "all the particular acts, which together shall constitute the offense, shall be detailed and itemized." "70 It has pointed out that in criminal proceedings where the statute adequately describes the nature of the offense it is generally sufficient for an indictment to follow the

72. See Caldwell, A Federal Administrative Court (1936) 84 U. OP PA. I REv. 965, 977; Chafee, State House v. Pent House (1937); and for a more recent expression of the same view which refers particularly to independent regulatory commissions, see Reorganization of Executive Departments, 75th Cong., 1st Sess., Sen. Doc. No. 8 (1937) 68:

"At the same time the independent commission is obliged to carry on judirial functions under conditions which threaten the impartial performance of that judicial worls. The discretionary work of the administrator is merged with that of the judge. Pressures and influences properly enough directed toward officers responsible for formulating and administering policy constitute an unwholesome atmosphere in which to adjudicate private rights. But the mixed duties of the commissions render escape from these subversive influences impossible.

"Furthermore, the same men are obliged to serve both as prosecutors and as judges. This not only undermines judicial fairness; it weakens public confidence in that fairness. Commission decisions affecting private rights and conduct lie under the suspicion of being rationalizations of the preliminary findings which the commission, in the role of prosecutor, presented to itself."

73. In the Matter of MI. J. Meehan, Securities and Exchange Commission, Release No. 404; In the Matter of Charles C. Wright, et al., Securities and Exinange Commission, Release No. 495; In the Matter of Harold T. White, et al., Securities and Exchange Commission, Release No. 621; In the Mfatter of W. E. Hutton, at., Securities and Exchange Commission, Release No. 932.

74. Ibid.

75. In the Miatter of M. J. Meehan, partial particulars furnished, request for additional particulars denied, 1 S.E.C. 238; In the Matter of Charles C. Wright, et al., certain particulars furnished subject to conditions, 1 S. E. C. 482.

76. In the Matter of Charles C. Wright, ef al., 1 S. E. C. 482, 484. 
language of the statute. ${ }^{77}$ The soundness of this conclusion turns on whether the anti-manipulative section of the Act is fairly analogous to an ordinary criminal statute. ${ }^{78}$ The Commission apparently believes it is. In the Wright case, ${ }^{7 \theta}$ after referring to Kanner $v$. United States, ${ }^{80}$ and quoting part of the opinion of Judge Swan to the effect that an indictment in substantially the words of a statute was sufficient in the case of a bankrupt charged with the crime of concealing assets, the opinion of the Commission then continues as follows:

"The Commission is of the opinion that these considerations are clearly controlling in the present proceeding. The offense charged is the manipulation of the price of a security on a national securities exchange by effecting certain transactions in that security in violation of Sections 9(a)(1) and 9(a)(2) of the Securities Exchange Act. It is in the nature of these transactions that they should be peculiarly within the knowledge of the respondents, and may be committed under circumstances which render impossible a specific description."

An examination of the records in these cases does not support the conclusion that the transactions constituting a violation of the antimanipulative section "should be peculiarly within the knowledge of the respondents." In the Meehan case the Commission found the respondent responsible for purchases made by customers of branch offices of other firms merely because the respondent, or somebody related to him, had advised customers' men of these branch offices that the security in ques:tion was "a good speculation" or "was a good buy." 81 To support this conclusion, the words of the statute "to effect either alone or with one or more other persons any series of transactions" must be construed to include transactions which will not be peculiarly within the knowledge of the respondent. The theory of the Meehan opinion seems in direct conflict with the analogy on which the Commission relied to justify its refusal of a detailed statement of particulars.

If the respondent is not fully apprised, by a bill of particulars or by a detailed allegation in the order to show cause, of the precise facts relied on to prove a violation of the Act, it is almost impossible for him to prepare for trial. The fact that administrative procedure is flexible, that adjournments may be freely granted, or that an opportunity to meet unexpected evidence may be furnished is not a sufficient answer. Effec-

77. Ibid.

78. Cf. Farmer's Livestock Commission v. United States, 54 F. (2d) 375 (E. D. III. 1931).

79. Ibid.

80. 21 F. (2d) 285 (C. C. A. 2d, 1927).

81. In the Matter of M. J. Meehan, Findings and Opinion of the Commission, Release No. 1331, at $17,18,24-25$. 
tive cross-examination must be based upon some knowledge of the facts as to which the witness will testify. In the case of expert testimony, it is important for counsel conducting the cross-examination to have an opportunity to confer with his own experts. In this connection I should also call attention to an important omission from the statute. Broad powers of subpoena are given to the Commission, ${ }^{82}$ but the respondent has no equivalent right. The Commission, as an act of grace, has made its subpoena power available to respondents charged with violating the anti-manipulative section of the Act. ${ }^{83} \mathrm{Had}$ this not been done the proceedings might have been almost $e x$ parte, as there is a natural reluctance on the part of persons who are themselves subject to regulation by the Commission to appear as witnesses against it. This method of giving respondents some opportunity of defending themselves does not cure the mistake, because the Commission in issuing the subpoenas learns the names of the witnesses to be called and the nature of the records to be produced on behalf of the respondent. With its unlimited powers of investigation, the Commission could subpoena the same witnesses and records for a preliminary investigation and would be able to ascertain in advance the precise nature of the respondent's case. I do not believe that the Commission or its staff have made unfair use of these powers. I merely call attention to the existence of the possibility.

There is another and more serious danger in the practice of having the Commission institute proceedings by a mere general allegation. If no sufficient investigation has been made before a proceeding under this section of the Act is instituted, it is possible that cases of this kind may become mere fishing expeditions launched in the hope that evidence of a violation of the Act may be found. If so employed, proceedings to suspend or expel members from national securities exchanges may become an effective means of oppression. The mere institution of an anti-manipulative proceeding carries with it a stigma which is harmful to the business of the respondent. In addition, he is faced with the burden and expense of defending himself. The cross-examination of numerous witnesses, the retention of experts to correct or offset expert opinion introduced on behalf of the Commission, the collection of evidence on his own behalf, appearing before a trial examiner wherever the Commission deems it convenient to hold hearings, and paying the cost of securing transcripts of lengthy hearings might constitute an intolerable burden. If, on the other hand, an adequate preliminary investigation has been made, it is difficult to see why the Commission

82. Securities Exchange Act of 1934, $\$ 21$ (d).

83. The Act does not expressly give a respondent the right to subpoenz witnecseg. However, it is a general practice of administrative commissions to issue subpoenzs for a respondent even though they are not required to. Comment (1937) 51 Hast. I. REv. 312, 315. 
should not furnish the respondent with a detailed statement of the facts on which it will rely to prove that the Act has been violated.

The use of trial examiners to take testimony in anti-manipulative cases is also open to question. The Commission has justified this course of conduct by reference to the approval which the courts have given to similar practices under other administrative statutes and also to the use in ordinary court proceedings of special masters and referees. There is much to be said in favor of the flexibility permitted by this procedure. When employed to collect statistical or other non-controversial evidence, it is not open to serious objection. The use of trial examiners in proceedings of a criminal nature, which necessarily involve sharp conflicts of testimony and the credibility of witnesses, is a different question. It is difficult to see how the Commission can fairly pass upon the guilt or innocence of a respondent without having seen the witnesses and heard them testify. The trial examiner in the Meehan case laid great stress upon the demeanor of witnesses in making his findings of fact. He said:

"Despite the fact that the witnesses in question were subpoenaed and placed on the stand by the Commission, I have felt free to place credence on part of their testimony while rejecting other portions.

In evaluating such testimony, I have borne in mind many factors and circumstances, including the demeanor and attitude of the witnesses; their comparative willingness or hesitancy in responding to the questions propounded by counsel; their apparent desire to shield themselves or the Respondent or to conceal the truth . . ."84

Appellate courts have been conscious of the danger of drawing conclusions from a printed record in regard to the credibility of witnesses. They do not set aside the findings of a trial judge, unless unsupported by or clearly contrary to the weight of the evidence. The Commission gives no such importance to the findings of its trial examiners and considers them as merely "advisory in character." 85

The proceedings under Section 19 (a) (3) have also caused difficulties in connection with the admission and use of evidence. Testimony taken during a preliminary investigation made by the Commission was employea for the purpose of impugning testimony subsequently given before the trial examiner. ${ }^{86}$ Transcripts of the testimony taken during a pre-

84. In the Matter of M. J. Meehan, Report and Findings of the Trial Examiner, 67.

85. In the Matter of M. J. Meehan, Findings and Opinion of the Commission, Release No. 1331, 37. The Commission stated that certain testimony of a Meehan partner was entitled to little credence. Id., at 17, n. 8 . The Commission in referring to the testimony of a witness stated, "We are inclined to disbelieve Wigmore's assertion that he acted independently of respondent in this transaction. His testimony is generally" unreliable." Id., at 20. See also id., at 28, n. 23.

86. In the Matter of M. J. Meehan, Official Report of Procecdings before the Securities and Exchange Commission, 220-240, 267, 1032-1040, 2346-2350. 
liminary investigation were refused to the respondents, although each witness who testified in such an investigation was furnished with a copy of his own testimony. ${ }^{87}$ No one who has examined the stenographic records of these cases can fail to be struck by the informality of the proceedings and by their great length. ${ }^{88}$ Evidence which was apparently irrelevant was freely admitted subject to later connection. ${ }^{69}$ Hearsay evidence, evidence referring to subjects and to periods which were outside the scope of the order to show cause or the bill of particulars, and even evidence based upon mere report and rumor were likewise admitted.90 It is only fair to note that the respondents were given equal latitude in introducing their evidence. But this type of evidence imposes

87. Numerous witnesses who testified at a preliminary investigation conducted by the Commission later purchased copies of their testimony which they either rurnished to or discussed with the respondent. In the Matter of M. J. Mechan, 1 S. E C. 238, 241 (1935) ; Report and Findings of Trial Examiner, 61. There is a strong inference that respondent requested copies of the testimony from the Commission and was refused. Testimony at the hearing bears this out. Furthermore, the Commission has contended that the preliminary investigations are of an entirely different character from the hearings and are more in the nature of grand jury proceedings. This view has baen sustained: "The character of the investigation, as a preparatory matter looking to the enforcement of the act, gives the basis for refusal to grant copies of the testimony." In re Securities and Exchange Commission, 84 F. (2d) 316, 318 (C. C. A. 2d, 1936).

88. The record of the testimony in both the Mrechan and W. E. Hutton hearings was approximately 6000 pages in length.

89. There are numerous instances of this. Where counsel urged that a later cennection would be shown it was the usual practice to allow the testimony to go in. See, e.g., conversations between third persons not in presence of respondent, In the Matter of Harold T. White, et al., Official Report of Proceedings Before the Securities and Exchange Commission, 320 et seq.; transactions in the alleged manipulated stock by third persons, id., at $575,1056,1073$ et seq. In respect to certain ai these transactions the Trial Examiner stated, "Therefore my feeling was and still is, subject to a later motion to strike, that all the beliefs, all of the attitudes and all of the transactions in that stock may be shown." Id., at 376. The Trial Examiner also recognized that this was not the most orderly method of procedure. Ibid. In his report the Trial Examiner in referring to respondent's motion to strike certain testimony stated: "The record contains motions to strike part of the testimony on which no ruling is indieated here since the testimony whether relevant or irrelevant, is not prejudicial." In the Matter of Harold $T$. White, Report and Findings of the Trial Essminer, 21. For other examples of admission of testimony subject to later motion to strilse if no connection were shown, see In the Mfatter of W. E. Hutton \& Co., Official Report of Proceedings before the Securities and Exchange Commission, 582, 600, 4 (485.

90. In the Matter of M. J. Meehan, Official Report of Procecdings before the Securities and Exchange Commission, 1219, 2406: In the Matter of Harold T. White, Official Report of Proceedings before the Securities and Exchange Commission, 953. 964, 989-993 (Evidence admitted outside of the period of time covered by the bill of particulars): In the Matter of W. E. Hutton \& Co., Official Reprit of Procecdings beiore the Securities \& Exchange Commission, 272 et seq. (Testimony as to transactions in Artlow stock was admitted although the order to show cause only charged manipulation of Atlas Tack stock). 
a heavy burden upon any court reviewing the proceeding ${ }^{01}$ and upon the Commission in reviewing the findings of the trial examiner, since both are forced to examine an extremely lengthy record containing much irrelevant matter. It also imposes a heavy burden on the respondent who must bear the expense of retaining a corps of experts for the period of the trial, which may be greatly extended by the trial-examiner's liberality in admitting evidence. Experience to date indicates that the Commission is more likely than the respondent to introduce seemingly irrelevant evidence subject to subsequent proof of relevance. Although the burden of proving relevance is upon the Commission in these cases, once the evidence is admitted the respondent must assume the burden of indicating the Commission's failure to connect such evidence with the issues of the case. This is tantamount to shifting the burden from the Commission to the respondent.

Another fact to be noted in regard to the use of trial examiners is that, with a single exception, ${ }^{22}$ they have been selected from the staff of the Commission. It is only natural that people belonging to the same organization may be partisan. In proceedings of this kind, however, where the trial examiner has great power to determine who should bear the burden of going forward, strict impartiality would seem to be essential. ${ }^{93}$ And it is doubtful whether respondents in these proceedings

91. The extreme burden placed on a reviewing court by a lengthy, cumbersome record was well pointed out in St. Joseph Stock Yards Co. v. United States, 298 U. S. 38 (1935) 86.

92. The only exception was In the Matter of Harold T. White in which Professor Thurman Arnold of the Yale School of Law sat as trial examiner.

93. In In the Matter of Harold $T$. White, a witness having testified that a list of transactions in the alleged manipulated stock on the New York Curb Exchange for a certain period had been prepared from ticker slips by his assistants and checked in part by him, the list was offered in evidence on behalf of the Commission; counscl for the respondents objected and the following colloquy ensued:

"Mr. O'Brien: I object to the admission of this on the ground that it is incompetent and irrelevant and not the best evidence. As this deals with what the Commission believes a vital feature of this case, the timing of the orders, I think that the original orders should be produced, so that we may check and examine them. ...

The Examiner: It will be admitted in evidence subject to a motion to strike if there is any error.

Mr. O'Brien: I don't want to appear to be delaying or requiring unnecessary proof, but this goes to the essence of this case; that is, it is part of the evidence, and it shows the times at which certain items are sold, and some of these I know to be inaccurate just from looking at them, but I don't know that from the records of the Curb Exchange but I know it because I have seen it on the order itself. I don't think that this should be received without some evidence more than has been received here.

The Examiner: I quite agree with you, but it is only a question of the quickest way to get errors, if any, corrected. Now, it would seem to 
will ever feel that they have been given an impartial trial under present conditions. Perhaps a solution to the problem may be found in the creation of an administrative court or an independent quasi-judicial bureau of trial examiners. The members of such a court or such examiners would, on the one hand, become experts at this type of work - thus satisfying the need for speed and efficiency in administration, and yet would be sufficiently removed from the domination of the Commission to satisfy the demand for protection of private rights.

These cases have necessarily involved a construction of the antimanipulative provisions of the statute and particularly of Section 9(a) (2). This is admittedly a difficult problem, and the views of the Commission on the scope of this section have not yet been made clear. Counsel for the Commission in the Meehan and White Weld cases have taken the position that any series of transactions raising or depressing the price of a security will constitute a violation, if effected for the purpose of inducing the purchase or sale of such security by others. They have likewise urged that any transaction may be said to have been effected by the respondent if it can be shown that any action on his part even remotely influenced others to buy or sell. ${ }^{04}$ They have argued that purchases made by a customer who overheard a favorable comment made by a partner of the respondent should be considered as transactions effected by the respondent. ${ }^{95}$ As pointed out above, the Commission itself has adopted a somewhat similar theory in finding that transactions by customers of branch offices of other firms might be attributed to the respondent merely because he had recommended the security to customer's men of such branch offices. ${ }^{08}$ If this construction is upheld, any purchase or sale, or any advice given in regard to securities, may be the foundation of a charge of manipulation provided a purpose to induce others to buy or sell can be proved. This latter element of the statutory crime is necessarily difficult of proof. Except in those rare

me that if $I$ am going to make $m y$ finding, $I$ am not going to read it before the end of this hearing, and it seems to me there is plenty of time to put the burden on counsel under the so-called 'best evidence' rule, would be to create a lot of proof on things that are not errors, you see.

Now why wouldn't it be quicker for this thing to go in temporarily subject to the correction of any errors, and then there is plenty of time

Mr. O'Brien: That is throwing the burden on me.

The Examiner: But really less of a burden than to go through the long two or three days of the other way."

In the Matter of Harold T. White, et al., Official Report of Proceedings bafore the Securities and Exchange Commission, 135-137.

94. In the Matter of M. J. Meehan, Findings and Opinion of the Commission, Securities and Exchange Release No. 1331, at 7.

95. Ibid.

96. Supra note 81 . 
cases where a person declares his intention in advance, it is difficult to determine the precise mental state giving rise to any human action. The difficulty becomes almost insuperable when the course of conduct of the respondent is equally consistent with a good or an evil purpose. ${ }^{07}$ This is generally true of transactions on exchanges. Any order to purchase more than a single unit of trading may result in a series of transactions. Orders to buy have a natural tendency to cause an increase in price, just as orders to sell are apt to result in price declines. Any purchase or sale is bound to result in actual or apparent active trading. As all the elements of a violation of the Act, except that of a purpose to induce others to buy or sell, may be present in any investment transaction, the judgment of the Commission becomes the controlling fact in determining whether the Act has been violated. It has been suggested that the purpose of inducing the purchase or sale of the security by others must be the dominant motive which actuated the respondent. The contrary view was taken by the trial examiner in the White Weld case who, after finding that the respondents had honestly believed the current price of the security was too low and that their purchases resulted, at least in part, from their desire to make a long term or semi-permanent investment, and that there was no evidence of any purpose to defratud or to sell securities at a price which the respondents did not believe to be a fair price reflecting the future prospects of the company, nevertheless concluded that the Act had been violated because "at least one of the purposes was to raise the price in order to distribute the stock." 08

In pointing out these difficulties I do not wish to minimize the good which has been accomplished by the anti-manipulative sections of the Act. There is no doubt these provisions and the somewhat similar provisions contained in the Securities Act of 1933 have enormously reduced the sale of worthless and fraudulent securities. The Commission deserves the highest praise for this achievement. I feel, however, that, without losing any of the good results of the statute, the whole question of manipulation should be realistically reconsidered. The word has never been defined, and it has no precise meaning. Because it is vague and nobody can be certain as to what is legitimate and what unlawful, these provisions of the Act have had the effect of preventing transactions which would have been greatly in the public interest in the narrow and illiquid markets of recent months.

This brief summary demonstrates, to my mind, some of the present tendencies of administrative law in the United States, as exemplified

97. For an analysis showing how a series of acts may give rise to conflicting hypotheses of purposes, each of which may be consistent with the questioned conduct, see Comment (1937) 46 Yale L. J. 624, 633-638.

98. In the Matter of Harold T. White, Report and Findings of the Trial Examiner, $14-21$. 
by the work of a single Commission. It raises also the question of whether the creation of independent regulatory commissions vested with legislative, executive and judicial powers does not constitute a threat to our democratic system of government. The dangers of such a concentration of power were almost prophetically anticipated by Elihu Root who, in his address before the American Bar Association in 1916, said:

"There is one special field of law development which has manifestly become inevitable. We are entering upon the creation of a body of administrative law quite different in its machinery, its remedies, and its necessary safeguards from the old methods of regulation by specific statutes enforced by the courts. *** There will be no withdrawal from these experiments. We shall go on; we shall expand them, whether we approve theoretically or not, because such agencies furnish protection to rights and obstacles to wrong-doing which under our new social and industrial conditions cannot be practically accomplished by the old and simple procedure of legislatures and courts as in the last generation. Yet the powers that are committed to these regulating agencies, and which they must have to do their work, carry with them great and dangerous opportunities of oppression and wrong. If we are to continue a government of limited powers these agencies of regulation must themselves be regulated. The limits of their power over the citizen must be fixed and determined. The rights of the citizen against them must be made plain." 98

The political dangers of such commissions have been morc recently recognized in the report of the President's Committee on Administrative Management. ${ }^{100}$

The importance of this question of redefining and limiting the powers of regulatory commissions cannot be over-emphasized. To freserve our traditional democratic institutions, two things must be accomplished. The basic right of individual freedom must be maintained, and at the

99. 41 A. B. A. Rep. 356, 368-9 (1916).

100. See Reorganization of the Executive Departments, 75th Cong., 1st Sess., Sen. Doc. No. 8 (1937) 67 :

"These independent commissions have been given broad powers to explore, formulate, and administer policies of regulation; they have been given the task of investigating and prosecuting business misconduct; they have been given powers, similar to those exercised by courts of law, to pass in concrete cases upon the rights and liabilities of individuals under the statutes. They are in reality miniature independent governments set up to deal with the railroad problem, the banking problem, or the radio problem. They constitute a headless 'fourth branch' of the Government, a haphazard deposit of irresponsible agencies and uncoordinated powers. They do violence to the basic theory of the American Constitution that there should be three major branches of the Government and only three. The Congress has found no effective vay of supervising them, they cannot be controlled by the President, and they are anstrerable to the courts only in respect to the legality of their activities." 
same time government must be made to function more effectively. These objectives are not mutually exclusive, but there is an unfortunate tendency on the part of extremists on both sides to make them appear irreconcilable. The protagonists of administrative law minimize the importance of individual rights and inveigh against our courts, which have been the traditional bulwark of individual, liberty. Reactionaries are equally vehement in denouncing any change which enlatges governmental power or seems to threaten the unrestrained right of the individual to do what he pleases. Little or no progress has been made in developing a program which will delimit, in the light of existing social and economic conditions, the function of government and the rights of the individual citizen. 